\title{
PAKISTAŃSKI PROGRAM NUKLEARNY W KONTEKŚCIE TYPOLOGII MODELI PROLIFERACJI SCOTTA D. SAGANA \\ Rafał Kopeć*
}

\author{
PAKISTANI NUCLEAR PROGRAM IN THE CONTEXT OF SCOTT \\ D. SAGAN'S MODELS OF NUCLEAR PROLIFERATION
}

\begin{abstract}
The aim of the paper is to present the Pakistani nuclear program in the context of Scott D. Sagan's models describing the causes of nuclear weapons proliferation. The typology consists of three models: the security, the domestic policy, and the norms. The author claims that the Pakistani program would be the most adequately present using the security model. The program was a response to both conventional and nuclear threat from India, which has been in permanent conflict with Pakistan.
\end{abstract}

\section{— KEYWORDS}

proliferation, security model, nuclear program

\section{WSTĘP}

Kluczową perspektywą do rozpatrywania zagadnienia proliferacji broni nuklearnej z punktu widzenia polityki międzynarodowej jest problematyka jej przyczyn. Motywy skłaniające poszczególne podmioty stosunków międzynarodowych do podjęcia wysiłku w kierunku pozyskania broni nuklearnej są różnorodne i nie

* Uniwersytet Pedagogiczny im. KEN w Krakowie, Instytut Bezpieczeństwa i Edukacji Obywatelskiej. 
ograniczają się tylko do kwestii bezpieczeństwa. Typologie modeli proliferacji, spośród których najbardziej znaną jest ta stworzona przez Scotta D. Sagana, odnoszą się właśnie do tego zagadnienia. Zasadniczy problem badawczy artykułu ująć więc można w następujący sposób: czy program rozwoju broni nuklearnej realizowany przez Pakistan może być w adekwatny sposób opisany za pomocą jednego z modeli proliferacji opracowanych przez Sagana, a jeśli tak - który $\mathrm{z}$ nich jest najbardziej odpowiedni?

Autor posłużył się metodą studium przypadku. Jej zastosowanie polegało na opisie danego zjawiska z uwzględnieniem określonego modelu teoretycznego. Autor skupia się na poszukiwaniu motywów skłaniających Pakistan do rozwoju militarnego programu nuklearnego i umiejscowieniu ich w kontekście jednego $\mathrm{z}$ trzech modeli proliferacji. Konkluzją artykułu jest ocena, które z czynników miały znaczenie kluczowe i jako takie mogą determinować przypisanie pakistańskiego programu nuklearnego do jednego z modeli Sagana.

\section{MODELE PROLIFERACJI}

Najbardziej znaną klasyfikację modeli proliferacji broni nuklearnej zaprezentował Scott D. Sagan w znanej pracy Why Do States Build Nuclear Weapons? Three Models in Search of a Bomb (Dlaczego państwa budują broń nuklearną? Trzy modele w ramach poszukiwań bomby $)^{1}$. Usystematyzował on modele proliferacji z uwzględnieniem kryterium jej przyczyn:

- model bezpieczeństwa (security model), wedle którego państwa budują broń nuklearną, by zwiększyć poziom bezpieczeństwa narodowego wobec zagrożeń zewnętrznych, zwłaszcza zagrożeń nuklearnych;

- model polityki wewnętrznej (domestic politics model), wedle którego broń nuklearna służy jako narzędzie polityczne w kontekście polityki wewnętrznej;

- model norm (norms model), wedle którego pozyskanie broni nuklearnej służy jako ważny symbol nowoczesności i tożsamości państwa².

Model bezpieczeństwa opiera się na apriorycznym założeniu, że ważne decyzje (pozyskanie broni nuklearnej) muszą mieć ważne podstawy (zagrożenie

1 S.D. Sagan, Why Do States Build Nuclear Weapons? Three Models in Search of a Bomb, „International Security" 1996/1997, vol. 21, no. 3, s. 54-86.

2 Ibidem, s. 55. 
bezpieczeństwa państwa). Państwo w obliczu groźby nuklearnej może podjąć decyzję o schronieniu się pod parasolem nuklearnym przyjaznego mocarstwa zgodnie z koncepcją rozszerzonego bezpieczeństwa (wiarygodność takich gwarancji w obliczu nuklearnej groźby jest jednak dyskusyjna) albo rozwinąć swój własny program. Według takiego ujęcia proliferacja pociąga proliferację (tzw. spiralna proliferacja) - rozwój arsenału nuklearnego przez jedno państwo skutkuje podjęciem analogicznych działań przez rywala.

Kolejnym czynnikiem mieszczącym się w modelu bezpieczeństwa, który motywuje państwa do budowy broni nuklearnej, jest zagrożenie ze strony sił konwencjonalnych przeciwnika. Najlepszym przykładem na funkcjonowanie tego mechanizmu jest program nuklearny Izraela. W modelu bezpieczeństwa mieści się również przypadek, kiedy państwo decyduje się na pozyskanie broni nuklearnej w celu zastosowania jej jako narzędzia zmiany balansu sił na scenie międzynarodowej na swoją korzyść. Jest to tzw. ofensywna odmiana modelu bezpieczeństwa, a przykładem jej obecności w stosunkach międzynarodowych był program nuklearny realizowany przez Irak.

Model bezpieczeństwa jest postrzegany przez Sagana jako intuicyjnie prawdopodobny, chociaż nie w każdym przypadku adekwatny. Przykładem może być program nuklearny Indii. Jego pierwsza faza (do testu nuklearnego w 1974 roku) posłużyła Saganowi jako przykład modelu polityki wewnętrznej, z kolei drugi etap (zwieńczony testami nuklearnymi w 1998 roku) może być w adekwatny sposób opisany za pomocą modelu norm.

\section{KORZENIE PAKISTAŃSKIEGO PROGRAMU NUKLEARNEGO}

Fundamenty koncepcji bezpieczeństwa Pakistanu, na której opierał się rozwijany przez to państwo militarny program nuklearny, opracowane zostały przez Zulfiqara Ali Bhutto na początku lat siedemdziesiątych. Ogólne zarysy tej koncepcji pozostają aktualne do dzisiaj. Bhutto został prezydentem Pakistanu w grudniu 1971 roku, tuż po klęsce w wojnie bengalskiej. Wojna bengalska miała olbrzymie znaczenie dla pakistańskiej percepcji bezpieczeństwa - po pierwsze, kosztowała utratę przez Pakistan prawie połowy terytorium na rzecz nowo powstałego państwa Bangladesz, po drugie, udowodniła, że w konwencjonalnej konfrontacji zbrojnej z Indiami Pakistan jest praktycznie pozbawiony szans na sukces. Co więcej, widmo takiej konfrontacji oznaczało nie tylko możliwość poniesienia 
kolejnej dotkliwej porażki militarnej, ale również stanowiło groźbę o charakterze egzystencjalnym, odnoszącą się do podstaw istnienia państwa.

Opracowana przez Bhutto i zaprezentowana w książce The Myth of Independence (Mit niepodległości) koncepcja bezpieczeństwa opierała się na idei wojny totalnej. Bhutto pisał: „Wojny w naszych czasach stają się wojnami totalnymi. Wszystkie europejskie strategie opierają się na koncepcji wojny totalnej. Musimy przyjąć, że wojna przeciwko Pakistanowi też może przekształcić się w wojnę totalną. Byłoby więc nierozważne przygotowywać się na konflikt o mniejszej skali, więc nasze planowanie musi zawierać nuklearne odstraszanie. Dla Pakistanu położenie największego możliwego nacisku na rozwój technologii nuklearnej ma znaczenie zasadnicze"3.

Oczywiście niebezpieczeństwo konfliktu totalnego wiązało się przede wszystkim z Indiami, więc przesłanki stojące za rozpoczęciem przez Pakistan militarnego programu nuklearnego są ukierunkowane ściśle na rywalizację pakistańsko-indyjską. Pakistańską determinację do budowy potencjału nuklearnego oraz percepcję zagrożenia ze strony Indii obrazuje wypowiedź Bhutto, który stwierdził, że „jeśli Indie skonstruują bombę atomową, my również ją skonstruujemy, choćbyśmy musieli jeść trawę lub głodować, gdyż nie ma żadnej konwencjonalnej alternatywy dla bomby atomowej"4.

Przekonanie, że Indie dążą do budowy broni nuklearnej, było w Pakistanie powszechne. Bhutto, jeszcze jako minister spraw zagranicznych w rządzie Muhammada Ayuba Khana (pełnił tę funkcję w latach 1963-1966), ostrzegał, że ostatecznym celem Indii będzie budowa bomby nuklearnej. $Z$ tej perspektywy Pakistan nie miał więc wyjścia. Broń nuklearna była niezbędna, żeby po pierwsze, pokrzyżować indyjskie plany nuklearnego odstraszania, po drugie, jako środek przeciwstawienia się groźbie konwencjonalnej ze strony Indii.

W pewnym sensie do rozpoczęcia programu nuklearnego przyczynił się traktat o nierozprzestrzenianiu broni nuklearnej z 1968 roku $^{5}$. W latach sześdziesiątych Pakistan nie zdecydował się na rozpoczęcie programu nuklearnego,

3 Z.A. Bhutto, The Myth of Independence, Nowy Jork 1969, s. 117.

${ }^{4}$ Cyt. za: B. Chakma, Strategic Dynamics and Nuclear Weapons Proliferation in South Asia, A Historical Analysis, Berno 2004, s. 136.

5 Założenia traktatu opierały się na arbitralnym podziale państw na nuklearne i nienuklearne. Za kryterium podziału uznano fakt wyprodukowania broni nuklearnej lub innego tego typu urządzenia wybuchowego przed 1 stycznia 1967 roku. Status państw nuklearnych zyskały więc Stany Zjednoczone, Związek Radziecki, Wielka Brytania, Francji i Chiny. Tekst traktatu: Treaty on the Non-Proliferation of Nuclear Weapons, http://www.iaea.org/Publications/Documents/Infcircs/Others/infcirc140.pdf, odczyt z dn. 28.04.2014. 
jednak pojawienie się w stosunkach międzynarodowych problematyki zapobiegania proliferacji broni nuklearnej zmusiło go do opowiedzenia się za lub przeciw nuklearyzacji. Pakistan zdecydował się pozostawić sobie „otwartą opcję nuklearną", nie podpisując traktatu (podobnie jak Indie) właśnie ze względu na podejrzenia i obawy względem sąsiada. Ta „otwarta opcja” po wojnie bengalskiej przekształciła się w program nuklearny.

\section{PRZESŁANKI PROGRAMU NUKLEARNEGO}

Bhutto rozpoczął prezydenturę 20 grudnia 1971 roku, a według Munira Ahmeda Khana, szefa Pakistańskiej Komisji Energii Atomowej, program militarny zapoczątkowany został na początku 1972 roku$^{6}$. Kwestia nuklearna traktowana była więc przez Bhutto jako priorytetowa. Realizacja programu nuklearnego była pochodną powiązanych ze sobą przesłanek:

- zagrożenia konwencjonalnego ze strony Indii (jego powagę ukazała wojna indyjsko-pakistańska w 1971 roku);

- podejrzenia, że Indie budują broń nuklearną (potwierdzone przez test nuklearny przeprowadzony w 1974 roku, określany przez Indie jako „pokojowa eksplozja nuklearna”; nie doprowadził on wprost do budowy przez Indie broni nuklearnej);

- założenia, że tylko broń nuklearna może zagwarantować przetrwanie państwa wobec połączonego - konwencjonalnego i nuklearnego - indyjskiego zagrożenia?

Głównym motywem stojącym za pakistańskim programem nuklearnym była percepcja zagrożeń. Model bezpieczeństwa opiera się bowiem nie tyle na rzeczywistych zagrożeniach, co na ich postrzeganiu w państwie podejmującym się proliferacji. Pakistan zawsze wykazywał pewną "nadwrażliwość” na punkcie zagrożenia indyjskiego. Jest to sytuacja typowa w relacjach państwa słabszego z silniejszym. Ze względu na kluczową rolę Indii w podziale Pakistanu w 1971 roku każda wypowiedź negująca zasadność podziału subkontynentu była traktowana jako atak na podstawy egzystencji Pakistanu. Obawy te podsycane były

${ }^{6}$ M.A. Khan, Nuclearisation of South Asia and Its Regional and Global Implications. Focus on Regional Issues, Islamabad 1998, s. 11.

${ }^{7}$ K. Sathasavian, „No Other Choice”: Pakistan's Decision to Test the Bomb, [w:] Integrating Cognitive and Rational Theories of Foreign Policy Decision Making, red. A. Mintz, Nowy Jork 2002, s. 56. 
przez uwidaczniające się w coraz większym stopniu od lat dziewięćdziesiątych mocarstwowe dążenia Indii. Dla Pakistanu bowiem relacje z Indiami były traktowane jako gra o sumie zerowej (podobnie zresztą postrzegane były w Indiach) każdy wzrost potęgi Indii automatycznie postrzegano przez pryzmat redukcji potencjału Pakistanu.

Taka percepcja wzajemnych stosunków była uwarunkowana zarówno przez wspólną historię (powstanie obu państw na drodze podziału subkontynentu, które kosztowało życie około miliona osób; kolejne konflikty zbrojne i kryzysy o charakterze militarnym), jak również przez jak najbardziej realne i aktualne kwestie sporne. Największe znaczenia miał - i nadal ma - nierozwiązany konflikt wokół Kaszmiru. Oprócz strategicznego znaczenia tego spornego terytorium ma ono również dla obu państw ogromne znaczenie symboliczne. Dla Pakistanu istnienie tak dużego skupiska ludności muzułmańskiej na terenie Indii podważa zasady, według których dokonano podziału państw (za pierwszoplanowe uznano kryterium religijne), oraz osłabia pozycję Pakistanu jako ojczyzny muzułmanów na subkontynencie (już powstanie Bangladeszu zachwiało tak formułowanymi podstawami istnienia tego państwa ${ }^{9}$ ). Dla Indii Kaszmir jest $\mathrm{z}$ kolei świadectwem możliwości istnienia państwa wieloreligijnego (jakim de facto są Indie), a jego ewentualna utrata mogłaby wyzwolić lawinę separatyzmów ze strony innych podmiotów dążących do secesji ${ }^{10}$.

\section{LATA OSIEMDZIESIĄTYCH - PRZYSPIESZENIE}

Pakistański program nuklearny przyspieszył w latach 80. Przyczyniła się do tego pomoc ze strony Chin, a także pobłażliwe traktowanie Pakistanu przez Stany Zjednoczone. Pakistan stał się dla USA ważnym sojusznikiem w rejonie Azji Środkowej, gdzie starano się stworzyć front powstrzymywania ekspansji komunizmu przejawiającej się w radzieckiej interwencji w Afganistanie, rozpoczętej

${ }^{8} \mathrm{Na}$ temat konfliktu w Kaszmirze i jego wpływu na bezpieczeństwo regionalne pisze Zdzisław Śliwa. Zob. Z. Śliwa, Konflikt w Kaszmirze, „Kwartalnik Bellona” 2009, nr 1, s. 81-89.

${ }^{9}$ Idea państwa muzułmańskiego była fundamentem, na którym utworzono Pakistan (Pakha-stan, czyli Kraj Ludzi Czystych, tj. wyznawców islamu; nazwę tę wymyślił Choudhary Rahmat Ali w 1934 roku). Wiązała się ona z wykreowaniem narodu muzułmańskiego w Azji Południowej, który powinien posiadać własne państwo. Zob. D.S. Zbytek, Azja Południowa: tygiel islamu i globalizacji, Warszawa 2010, s. 236-244.

10 R. Włoch, Nowa era nuklearna: analiza indyjsko-pakistańskiego kryzysu nuklearnego z maja 1998 roku, Toruń 2004, s. 38-39. 
w 1979 roku. Administracja Ronalda Reagana zarzuciła politykę prowadzoną przez Jimmy’ego Cartera, który ograniczył, a następnie wstrzymał pomoc wojskową i gospodarczą dla Pakistanu właśnie w związku z podejrzeniami o rozwijanie broni nuklearnej. W latach 1981 i 1986 Pakistan otrzymał od Stanów Zjednoczonych dwie transze pomocy gospodarczej i wojskowej, a w latach 1983-1987 Amerykanie dostarczyli 40 nowoczesnych myśliwców F-16 w ramach programów Peace Gate I i II ${ }^{11}$.

Pakistan uzyskał zdolność nuklearną (wszedł w posiadanie możliwej do operacyjnego zastosowania broni nuklearnej) około roku 1987. Szef pakistańskiego programu nuklearnego dr Abdul Khan udzielił w 1998 roku wywiadu, w którym przyznał, że Pakistan uzyskał możliwość przeprowadzenia detonacji ładunku nuklearnego już w końcu 1984 roku $^{12}$. Weryfikację poprawności konstrukcji prowadzono w oparciu o tzw. zimne testy nuklearne. Pierwszy taki test został przeprowadzony prawdopodobnie w 1983 roku, a do roku 1990 wykonano około 25 tego typu prób ${ }^{13}$. Rozbudowano również arsenał środków przenoszenia - do przenoszenia broni nuklearnej dostosowano samoloty, realizowano program budowy rakiet balistycznych, najpierw bliskiego zasięgu Haft, potem średniego zasięgu Ghauri.

Uzyskanie zdolności nuklearnej zbiegło się w czasie ze sprawdzeniem w praktyce koncepcji odstraszania nuklearnego, które zastosowano po raz pierwszy w czasie kryzysu Brasstacks w latach 1986-1987. Odstraszanie stosowano w sposób zawoalowany, gdyż proliferacja w przypadku Pakistanu miała charakter ukryty ${ }^{14}$ (nie przyznano się oficjalnie do posiadania broni nuklearnej, nie przeprowadzono też testu nuklearnego). Przyczyną kryzysu było zorganizowanie przez Indie olbrzymich, angażujących siły 10 dywizji, ćwiczeń w północnym Radżastanie. Rejon ten stanowi najbardziej prawdopodobną „bazę wypadową” do agresji na teren Pakistanu. Strona pakistańska postrzegała manewry jako przygotowanie do ataku na swój kraj. W sytuacji ogromnego napięcia mię-

\footnotetext{
11 Ł. Pacholski, Pakistańskie F-16, „Nowa Technika Wojskowa” 2010, nr 2, s. 80.

12 P.K. Kerr, M.B. Nikitin, Pakistan's Nuclear Weapon: Proliferation and Security Issues, CRS Report for Congress, Waszyngton 2011, s. 4.

${ }^{13}$ R. Włoch, op.cit., s. 45.

14 Termin ukrytej/nieprzeźroczystej (opaque) proliferacji ukuty został przez Benjamina Frankela i ma zastosowanie w stosunku do podmiotów, które mają możliwości militarnego wykorzystania broni masowego rażenia (z czego zdają sobie sprawę inni uczestnicy stosunków międzynarodowych), ale nie deklarują tego oficjalnie (np. nie przeprowadzają próbnej eksplozji nuklearnej). Zob. A. Cohen, B. Frankel, Opaque Nuclear Proliferation, [w:] Opaque Nuclear Proliferation. Methodological and Policy Implications, red. B. Frankel, Portland 1991, s. 14-41.
} 
dzynarodowego dyrektor pakistańskiego programu nuklearnego dr Abdul Khan udzielił 28 stycznia 1987 roku wywiadu prominentnemu dziennikarzowi indyjskiemu Kuldipowi Nayarowi, w którym stwierdził: „niech będzie jasne, że użyjemy bomby, gdy nasza egzystencja będzie zagrożona"15.

Kolejnym sprawdzianem skuteczności nuklearnego odstraszania stał się kryzys wokół Kaszmiru w 1990 roku. Reakcją na rzekome plany Indii dotyczące powietrznych uderzeń na obozy treningowe powstańców na terenie Pakistanu było zorganizowanie konwoju ciężarówek z miejsc prawdopodobnego składowania broni jądrowej do bazy sił powietrznych i postawienie w stan gotowości bojowej znajdujących się tam samolotów F-16 w taki sposób, by wywiad przeciwnika doszedł do przekonania, iż Pakistan jest w każdej chwili gotowy dać sygnał do startu samolotów uzbrojonych w broń nuklearną. Kryzys zażegnała interwencja dyplomatyczna Stanów Zjednoczonych. Według źródeł indyjskich państwo to było przekonane, że Pakistan nie jest w posiadaniu operacyjnych ładunków nuklearnych, które można dostarczyć do celu za pomocą samolotów ${ }^{16}$, ale z punktu widzenia Pakistanu kryzys w Kaszmirze był kolejnym potwierdzeniem skuteczności strategii nuklearnego odstraszania ${ }^{17}$.

Paradoksalnie w okresie dynamicznego rozwoju pakistańskiego programu nuklearnego program indyjski - który wszak stanowił kluczową przesłankę wysiłków Islamabadu - pozostawał nadal „otwartą opcją”. Indie nie zdecydowały się w tym czasie na ostateczne nadanie swojemu programowi wymiaru militarnego (pozostawał w stadium tzw. non-weaponized). Jak już zostało podkreślone, nie tyle jednak rzeczywiste zagrożenia warunkują proliferację broni masowego rażenia w modelu bezpieczeństwa, co ich percepcja.

Z punktu widzenia Pakistanu kraj ten pod każdym względem ustępował Indiom, a wysiłki w celu zminimalizowania różnicy potencjałów - przede wszystkim na polu broni konwencjonalnej - skazane były na niepowodzenie. Realizacja przez Indie testu nuklearnego w 1974 roku oznaczała, że Indie zyskały przewagę w kolejnej dziedzinie, tym razem w zakresie „broni absolutnej”. To było zupełnie nie do przyjęcia z punktu widzenia interesów bezpieczeństwa Pakistanu.

15 P.R. Chari, Nuclear Crisis, Escalation Control, and Deterrence in South Asia, Waszyngton 2003, s. 15.

16 Ibidem, s. 17.

17 B. Chakma, Pakistan's Nuclear Doctrine and Command and Control System: Dilemmas of Small Nuclear Forces in the Second Atomic Age, „Security Challenges” 2006, vol. 2, no. 2, s. 119. 
Percepcja zagrożenia była potęgowana przez poczucie strategicznego osamotnienia. Elity pakistańskie zdawały sobie sprawę, że w konfrontacji z indyjską potęgą nie będą mogły liczyć praktycznie na żadnego sojusznika. A konfrontacja taka przerodzić mogła się, zgodnie z koncepcjami Bhutto, w konflikt totalny, mogący prowadzić do fizycznego unicestwienia państwa pakistańskiego. W takiej sytuacji rachuby zakładające sformowanie antyindyjskiej koalicji albo w oparciu o państwa regionu Azji Południowej, albo o państwa islamskie skazane były na porażkę. Sukcesem nie zakończyły się również wysiłki w kierunku oparcia bezpieczeństwa Pakistanu na relacjach ze Stanami Zjednoczonymi i budowanych pod ich auspicjami regionalnych sojuszach: SEATO (South East Asia Treaty Organization) i CENTO (Central Treaty Organization). Podczas konfliktu o Kaszmir w 1965 roku państwa skupione w tych organizacjach udzieliły Pakistanowi tylko poparcia materialnego i dyplomatycznego, a Stany Zjednoczone wręcz zamroziły pomoc wojskową. W czasie wojny bengalskiej Waszyngton ograniczył się do symbolicznego gestu w postaci wpłynięcia lotniskowca USS Enterprise do Zatoki Bengalskiej ${ }^{18}$. Pakistan nie mógł również w przypadku zagrożenia egzystencji państwa liczyć na Chiny. Co prawda chętnie wykorzystywały one każdą okazję do osłabienia Indii z pomocą Pakistanu, ale nie zdecydowały się nawet na gest poparcia stanowiska Islamabadu w kwestii Kaszmiru, nie mówiąc o stworzeniu bardziej sformalizowanego sojuszu. Co gorsza, po zakończeniu zimnej wojny oraz radzieckiej interwencji w Afganistanie Pakistan przestał być niezbędnym sojusznikiem Stanów Zjednoczonych, co zaowocowało zakończeniem polityki „patrzenia przez palce” na pakistański program nuklearny przez administrację w Waszyngtonie. W 1990 roku prezydent George Bush nie potwierdził, że Pakistan nie posiada broni nuklearnej, co automatycznie uruchomiło mechanizm poprawki Presslera, skutkujący wstrzymaniem wszelkiej pomocy dla Pakistanu ${ }^{19}$.

18 M.K. Roy, December 1971: Indo-Pakistani Conflict at Sea, http://www.indiandefencereview.com/ military-and-aerospace/December-1971-Indo-Pakistani-conflict-at-sea---IV.html, odczyt z dn. 8.03.2012.

19 Poprawka Presslera (Pressler amendment) zakładała, że Stany Zjednoczone nie mogą udzielać Pakistanowi żadnej pomocy ani sprzedawać broni, jeśli prezydent wcześniej nie potwierdzi, że Pakistan nie posiada broni nuklearnej (w rozumieniu urządzenia zdolnego do spowodowania wybuchu nuklearnego) oraz że nowa pomoc w znaczący sposób zredukuje ryzyko, że Pakistan wejdzie w posiadanie takiego urządzenia w przyszłości. H. Fitzgerald, Robert Gates, Pakistan \& The Pressler Amendment, http://www.newenglishreview.org/Hugh_Fitzgerald/Robert_Gates,_Pakistan_\%26_ The_Pressler_Amendment/,odczyt z dn. 11.04.2014. 


\section{W KIERUNKU PROLIFERACJI JAWNEJ}

Postępy Pakistanu w zakresie budowy broni nuklearnej i zastosowanie nuklearnego odstraszania skłoniły Indie do militaryzacji swojego programu (przejścia do stadium weaponized). Miało to miejsce około 1990 roku. W maju 1994 roku indyjski system broni nuklearnej wraz ze środkami przenoszenia był gotowy do operacyjnego zastosowania ${ }^{20}$. Indyjskie zdolności pozwoliły więc na stosunkowo szybkie pozyskanie operacyjnej broni nuklearnej, a Pakistan w latach dziewięćdziesiątych zmuszony został do wysiłku w celu dotrzymania kroku Indiom w zakresie programu nuklearnego i rakietowego.

Wygrana Bharatiya Janata Party (BJP) w indyjskich wyborach parlamentarnych w 1998 roku skutkowała skokowym wzrostem poczucia zagrożenia dla Pakistanu. Partia ta deklarowała „zrobienie użytku z programu nuklearnego" i można było zakładać, że zrealizuje przedwyborcze zapowiedzi ${ }^{21}$. Rzecznik Ministerstwa Spraw Zagranicznych Pakistanu Tariq Altaf ostrzegał, że „otwarte pogróżki odnoszące sie do możliwości wykorzystania opcji nuklearnej tworzą groźną sytuację. Zwielokrotnia to zagrożenie dla bezpieczeństwa Pakistanu, stanowiąc poza tym poważny cios w globalne i regionalne wysiłki w kierunku nuklearnej nieproliferacji” ${ }^{22}$. Na wynik wyborów Pakistan zareagował początkowo ostrożnie, czekając na ewentualne nieuzyskanie przez rząd wotum zaufania. Po tym jednak, jak w marcu 1998 roku rząd sformowany przez BJP rozpoczął urzędowanie, dla pakistańskiego rządu stało się jasne, że indyjskie próby są kwestią czasu. Uznanie testów nuklearnych za czynnik w sposób zasadniczy zakłócający równowage w regionie skłoniło Pakistan do podjęcia ofensywy dyplomatycznej w celu zapobieżenia urzeczywistnieniu się tego zagrożenia. Liczono, iż presja Stanów Zjednoczonych na Indie spowoduje rezygnację z testów. Postawa Waszyngtonu była jednak niejednoznaczna i mało konsekwentna. Chwiejne stanowisko amerykańskiej administracji spowodowało, że Pakistan zaczął obawiać się, że Indie zechcą uzyskać status nuklearny bez testów, ale na drodze stopniowych postępów (np. symulacji komputerowych) skorelowanych z kolejnymi umowami ze Stanami Zjednoczonymi przesuwającymi stopniowo próg tolerancji Waszyngtonu na nuklearny status Indiii ${ }^{23}$. Postanowiono więc zareagować, przeprowadzając 6

20 R. Włoch, op.cit., s. 62.

${ }^{21}$ Ibidem, s. 70.

22 New Government in India Heightens Nuclear Concerns, http://www.acronym.org.uk/dd/ dd24/24new.htm, odczyt z dn. 12.04.2014.

23 R. Włoch, op.cit., s. 71-72. 
kwietnia 1998 roku test rakiety balistycznej średniego zasięgu Ghauri ${ }^{24}$. Indie potraktowały test rakiety zdolnej dosięgnąć większość indyjskich miast jako zakłócenie równowagi w regionie i odpowiedziały serią testów nuklearnych.

Sama decyzja, czy odpowiadać na testy indyjskie przeprowadzeniem własnych testów, stanowi argument za modelem polityki wewnętrznej. Członkowie rządu Nawaza Sharifa, znajdując się pod presją ze strony Stanów Zjednoczonych, wypowiadali się początkowo ostrożnie i nie przesądzali sprawy pakistańskich testów. Rząd spotkał się jednak z naciskami ze strony sił zbrojnych i środowiska naukowego. 11 maja 1998 roku głównodowodzący armii Jahangir Karamat zapowiedział, że Pakistan „rezerwuje sobie możliwość podjęcia wszelkich koniecznych środków odpowiedzi na indyjskie groźby”25. Doktor Adbul Khan zadeklarował, że może w ciągu tygodnia zrealizować całą procedurę przygotowawczą do testów i wezwał rząd do podjęcia takiej decyzji ${ }^{26}$. Sharif z jednaj strony nie miał wyjścia (w przypadku nieprzeprowadzenia testów rząd prawdopodobnie by upadł), $\mathrm{z}$ drugiej nacisk wewnętrzny stanowił wygodny pretekst do wykorzystania na arenie międzynarodowej. W celu uwypuklenia czynnika wewnętrznego rząd powołał komisję, która miała przeprowadzić konsultacje polityczne w kraju (oczywiście opowiedziano się za testami) ${ }^{27}$.

\section{WYJŚCIE Z UKRYCIA}

Sytuacja była jednak otwarta - choć rezygnacja z testów mało prawdopodobna - do drugiej serii testów indyjskich przeprowadzonych 13 maja 1998 roku (dwa dni po pierwszej serii). Działanie takie uznano za objaw zupełnego lekceważenia przez Indie społeczności międzynarodowej. Stany Zjednoczone co prawda rozpoczęły ofensywę dyplomatyczną w celu zahamowania pakistańskich testów, obiecując szereg korzyści, ale pozbawiona była ona szans powodzenia. Jedynym czynnikiem, który mógłby powstrzymać Pakistan, było nałożenie na Indie skoordynowanych sankcji przez grupę G-8, co jednak nie nastąpiło. Rozkaz przeprowadzenia testów został wydany 18 maja 1998 roku, w następstwie

24 S. Zaloga, Pakistan buduje nuklearne siły uderzeniowe, „Raport - Wojsko Technika Obronność” 2000, nr 10, s. 36.

25 R. Włoch, op.cit., s. 90.

${ }^{26}$ Interview with Abdul Qadeer Khan, http://nuclearweaponarchive.org/Pakistan/KhanInterview. html, odczyt z dn. 8.03.2014.

27 R. Włoch, op.cit., s. 90. 
narady Rządowego Komitetu Obrony (Defense Committee of the Cabinet, DCC). Odbyła się ona 16 lub 17 maja 1998 roku, a oprócz premiera uczestniczyli w niej ministrowie spraw zagranicznych (Gohar Ayub Khan) i finansów (Sartaj Aziz) oraz głównodowodzący wszystkich trzech rodzajów sił zbrojnych ${ }^{28}$.

Do takiej decyzji przyczyniły się również działania ze strony Indii, które celowo eskalowały kryzys, zdając sobie sprawę z wrażliwości pakistańskich elit politycznych na czynnik indyjskiego zagrożenia. Władze Indii najprawdopodobniej sądziły, że Pakistan praktycznie nie ma wyjścia i musi zareagować na indyjskie testy, a być może nawet uważały taki rozwój sytuacji za korzystny. Po pierwsze, ukazywał on, że zagrożenie ze strony Pakistanu oraz zaawansowanie jego programu nuklearnego stanowiły słuszne uzasadnienie własnych testów. Po drugie, skoro Indie narażały się na sankcje ze strony społeczności międzynarodowej i przyjęły na siebie odium państwa łamiącego międzynarodowe normy, korzystne było, by analogiczne konsekwencje dotknęły również Pakistan. Po trzecie, testy przeprowadzone przez dwa państwa w większym stopniu podważały kontestowany przez Indie reżim nieproliferacji broni nuklearnej29. Co więcej, ewentualne testy Pakistanu nie miały większego znaczenia z militarnego punktu widzenia, gdyż oba kraje niezależnie od tego dysponowały już operacyjną bronią nuklearną.

Świadoma eskalacja kryzysu ze strony Indii polegała na prowokacyjnych wypowiedziach przedstawicieli indyjskich władz. Przykładem może być oświadczenie ministra spraw wewnętrznych Lala Krishny Advaniego, który stwierdził, że testy stworzyły warunki do trwałego rozwiązania kwestii Kaszmiru, a Pakistan powinien zdać sobie sprawę ze zmiany sytuacji geostrategicznej i wycofać się $\mathrm{z}$ antyindyjskiej polityki ${ }^{30}$. Była to oczywista groźba wykorzystania uzyskanej przewagi w kwestii, która dla obu stron miała znaczenie zasadnicze. Pakistan nie był tymczasem gotowy na żaden kompromis w sprawie Kaszmiru. Związana z BJP radykalna organizacja Vishnu Hindu Parishar wezwała do podjęcia przygotowań do czwartej wojny z Pakistanem ${ }^{31}$. Eskalacji napięcia towarzyszyły niepokojące wydarzenia na linii kontroli w Kaszmirze, gdzie doszło do wymiany

28 R. Akhtar, Nuclearization of Pakistan: Motivations and Intentions, s. 22, http://www.dodccrp. org/events/10th_ICCRTS/CD/papers/087.pdf, odczyt z dn. 8.03.2012.

${ }^{29}$ R. Włoch, op.cit., s. 93.

30 V.D. Cha, Nuclear Weapons, Missile Defense, and Stability, [w:] Asian Security Order: Instrumental and Normative Features, red. M. Alagappa, Stanford 2003, s. 469.

31 R. Włoch, op.cit., s. 96. 
ognia między wojskami Indii i Pakistanu. Dla Islamabadu działania te stanowiły rodzaj nuklearnego szantażu. Uważano, że Indie zamierzają wykorzystać zdobytą przewagę strategiczną, by rozwiązać po swojej myśli kwestię Kaszmiru. Z perspektywy Pakistanu równowaga została w sposób dramatyczny zakłócona i tylko własne testy nuklearne mogły ją przywrócić.

W Pakistanie narastało również przekonanie o możliwej groźbie bezpośrednich działań zbrojnych ze strony Indii. Oprócz kwestii Kaszmiru obawiano się ataku na pakistańskie instalacje nuklearne w celu uniemożliwiania przeprowadzenia testów. Niezależnie od tego, czy takie niebezpieczeństwo rzeczywiście istniało - a wydaje się to mało prawdopodobne - pakistańskie obawy były realne. Z punktu widzenia modelu bezpieczeństwa to właśnie one pełnią kluczową rolę przy podejmowaniu decyzji o proliferacji broni masowego rażenia. Ważne jest bowiem nie tyle realne zagrożenie, co jego percepcja. Właśnie ona zaważyła ostatecznie na decyzji o przeprowadzeniu testów, które odbyły się 28 i 30 maja 1998 roku.

\section{WNIOSKI}

Pakistański program nuklearny w najbardziej adekwatny sposób można opisać za pomocą modelu bezpieczeństwa. Był on uwarunkowany przede wszystkim zagrożeniem ze strony Indii. Należy podkreślić, że było to zarówno zagrożenie konwencjonalne, jak i nuklearne. Powagę zagrożenia konwencjonalnego ukazała wojna indyjsko-pakistańska w 1971 roku. W wyniku wyniesionych z niej doświadczeń (utrata znacznej części terytorium) narosła obawa przed możliwością całkowitej likwidacji Pakistanu jako państwa w wyniku konfliktu konwencjonalnego na dużą skalę. Konflikt taki niewątpliwie zakończyłby się klęską Pakistanu ze względu na jego słabość we wszystkich kluczowych dla jego wyniku aspektach (potencjał sił zbrojnych, potencjał demograficzny, przemysłowy, wielkość terytorium i głębia strategiczna). Wobec takiego stosunku sił Pakistan nie mógł dopuścić do uzyskania przez Indie przewagi w kolejnym obszarze, jakim był potencjał nuklearny. Co ważne, na decyzji o pozyskaniu broni nuklearnej zaważyła nie tyle analogiczna decyzji Indii, co podejrzenia, że rywal taką decyzję może podjąć, wzmocnione przez indyjski test nuklearny z 1974 roku (samo przekształcenie indyjskiego potencjału nuklearnego w operacyjnie użyteczną broń miało jednak miejsce znacznie później). Przesłanki te były wzmacniane 
przez poczucie strategicznego wyalienowania wobec braku możliwości oparcia bezpieczeństwa o ścisły sojusz z jednym z mocarstw - USA bądź Chinami.

W ramach modelu bezpieczeństwa kluczową rolę pełni percepcja zagrożeń. Warto bowiem zwrócić uwagę, że decyzja o nadaniu pakistańskiemu programowi nuklearnemu statusu operacyjnego została podjęta w okresie, gdy Indie jeszcze swojego programu nie militaryzowały. Zagrożenie miało więc charakter przede wszystkim potencjalny. Z punktu widzenia Pakistanu był to jednak czynnik o realnym znaczeniu. Na decyzji o konieczności posiadania broni nuklearnej zaważyły także sukcesy - z perspektywy pakistańskiej - odstraszania nuklearnego względem Indii. I znów mniejsze znaczenie ma dylemat, czy indyjskie niebezpieczeństwo rzeczywiście istniało, oraz to, czy zawoalowane odwołanie się do broni nuklearnej zapobiegło jego urzeczywistnieniu, kluczowe jest bowiem postrzeganie tych wydarzeń z pakistańskiego punktu widzenia. Znaczenie percepcji zagrożeń, a nie tyle ich obiektywnego istnienia, dla proliferacji broni nuklearnej w ramach modelu bezpieczeństwa potwierdza sekwencja wydarzeń tuż przed testami pakistańskimi, kiedy to Indie celowo podsycały obawy kierownictwa pakistańskiego, chcąc najprawdopodobniej sprowokować ten kraj do otwartej deklaracji nuklearnego statusu.

Przesłanki sytuujące się poza modelem bezpieczeństwa, np. z dziedziny polityki wewnętrznej, miały znaczenie drugorzędne i wykorzystywane były raczej jako pretekst na arenie międzynarodowej, nie wpływając jednak decydująco na przebieg programu. 